\title{
Analysis of Interaction Behaviors in Children with Cochlear Implants by Tait Video Method
}

\author{
Yun-Hee Jung ${ }^{\mathrm{a}}$, Mi-Sun Yoon ${ }^{\mathrm{b}}$ \\ ${ }^{a}$ Department of Communication Disorders, Graduate School, Korea Nazarene University, Cheonan, Korea \\ ${ }^{b}$ Department of Communication Disorders, Korea Nazarene University, Cheonan, Korea
}

Correspondence: Mi-Sun Yoon, $\mathrm{PhD}$

Department of Communication Disorders, Korea Nazarene University, 48 Wolbong-ro, Seobuk-gu, Cheonan 31172, Korea

Tel: +82-41-570-1412

Fax: $+82-41-570-7846$

E-mail: msyoon@kornu.ac.kr

Received: April 5, 2016

Revised: May 14, 2016

Accepted: May 28, 2016

This work was modification of the master's thesis of the first author.

\begin{abstract}
Objectives: The purpose of this study was to evaluate the development of interaction behaviors in children with cochlear implants by using Tait video analysis. Methods: The participants were 27 children: 9 with cochlear implants (Cl group), 9 language age-matched (LA group), and 9 chronological age-matched (CA group). Their interaction behaviors were assessed based on 3 indices while interacting with the researcher: turn-taking, autonomy, and auditory awareness. Each of these indices can be either vocal or gestural. Turn-taking is when the child takes an appropriate opportunity to communicate during interaction. Autonomy is when the child initiates the interaction. Auditory awareness is when the child replies to a sound cue without a corresponding visual cue. Mixed-ANOVA was used to analyze the data. Results: $\mathrm{Cl}$ group was not significantly different from LA group in any evaluation variable. However, there were significant differences in the frequency of vocal turntaking, gestural turn-taking, and non-looking vocal turns between the $\mathrm{Cl}$ group and the CA group; whereas the differences between the two groups in the frequency of vocal autonomy, gestural autonomy, and non-looking gestural turns were not significantly different. Conclusion: The results showed that $\mathrm{Cl}$ children who received early diagnosis and intervention displayed a similar developmental pattern of interaction to LA children.
\end{abstract}

Keywords: Cochlear implant for infants, Interaction evaluation, Turn-taking, Autonomy, Auditory awareness
청각에 문제가 없는 일반 영유아들은 사회적 상호작용을 통해 언어를 습득한다(Owens, 2005). 언어발달은 정서, 인지, 사회성 등 의 다양한 발달에도 중요한 역할을 하므로 언어발달 초기 영유아 와 성인과의 사회적 상호작용은 아동의 전반적 발달을 위해서 중요 하다. 반면 선천성 고심도 청각장애 영유아들은 듣기의 제한으로 상호작용 뿐만 아니라 언어와 사회성 발달 등에서 어려움을 겪을 수 있다(Quittner, Leibach, \& Marciel, 2004). 하지만 청각장애 영 유아들도 조기진단과, 조기중재를 통해 일반언어발달 패턴과 속도 를 따라갈 수 있다는 연구들이 보고되고 있다(Nicholas \& Geers, 2006). 청각장애 영유아의 성공적인 조기중재를 위해서는 청각장 애의 특성에 맞는 의사소통능력 평가가 이루어져야 한다(Yoon, 2010). 청각장애 영유아의 의사소통 평가에는 말지각능력 평가, 말 과 언어발달의 평가, 상호작용 평가가 포함된다(Yoon \& Choi, 2010).
상호작용에서 나타나는 의사소통 기술들은 훗날 언어발달을 예측 하는 지표의 역할을 하므로 영유아의 의사소통 평가에서 중요한 평가 영역이다(Guerzoni et al., 2015; Hong \& Kim, 2005; Rinaldi, Baruffaldi, Burdo, \& Caselli, 2013). 청각장애 영유아의 상호작용 평가로 일반적으로 의사소통의도가 사용되고 있으며 의사소통의 도의 발달은 국내외에서 청각장애 영유아를 대상으로 연구가 다수 진행되었다. 청각장애 아동의 경우에도 의사소통의도의 발달은 언 어발달에서 중요한 선행지표로 보고된다(Nicholas, 1994; Nicholas, Geers, \& Kozak, 1994; Spencer, 1993; Sung, Yoon, \& Hong, 2010; Yeon, 2001)

Rinaldi 등(2013)은 2세 이전에 와우이식을 받은 청각장애 영유 아를 대상으로 부모설문을 통해 상호작용 능력에 대한 평가를 실 시하였다. 연구 결과, 아동들은 차례맡기에서 초기 사회적 화용 기 
술에 어려움을 보이고 있어 청각장애 영유아의 사회적 기술에 대 한 조기중재가 필요한 것으로 나타났다. 청각장애 영유아의 상호작 용에서의 의사소통의도를 평가한 선행연구들에서는 청각장애 영 유아들이 생활연령을 일치시킨 일반 영유아보다 의사소통의도 산 출 빈도가 유의하게 낮았으며(Sung et al., 2010; Yeon, 2001; Nicholas et al., 1994) 언어연령을 일치시킨 일반 영유아보다는 산출 빈도 가 높았다(Nicholas et al., 1994).

청각장애 영유아의 언어이전기 상호작용 평가방법으로 Rinaldi 등(2013)은 부모설문을 사용하였다. 부모설문에 의한 평가는 아동 의 의사소통 능력에 대한 정보를 제공할 수 있으나 이는 간접적인 평가인 만큼 아동의 상호작용을 평가하는 데는 한계가 있다. Kane, Schopmeyer, Mellon, Wang 그리고 Niparko (2004)는 청각장애 영 유아집단에 Communication and Symbolic Behavior Scales (CSBS) 검사를 실시하여 의사소통 능력을 평가하였다. CSBS에서 측정된 의사소통 기술과 이후 언어능력과는 정적상관을 보였으나, CSBS 는 청각장애 아동의 특성이 반영된 평가 항목이 없는 것이 제한점 으로 지적되었다. 또한 선행연구에서 주로 사용되고 있는 의사소통 의도 분석은 분석 과정에서 시간과 노력이 필요하며, 청각장애 아 동들의 특성인 청각적 수행력이 고려되지 않아 실제 임상에서 사 용하기에 제한점이 있었다. 따라서 청각장애 영유아의 특성에 적합 하고 임상에서 간단하게 실시할 수 있으며, 언어발달을 예측할 수 있는 언어이전기의 상호작용능력 평가가 더욱 요구된다.

Tait (1993)는 청각장애 영유아의 조기중재 프로그램의 일환으 로 차례맡기에 중점을 둔 상호작용 평가를 제안하였다. 'Tait 비디 오 분석법이라고 하는 이 상호작용 평가는 엄마와 아동의 상호작 용을 5-10분 정도 비디오로 녹화하여 차례맡기(turn-taking), 개시 성(autonomy), 청각적 인식(auditory awareness)의 세 지표로 평가 하는데, 기존의 상호작용 평가 방법에 비해 평가 시간이 짧으며 분 석이 용이하다. 차례맡기는 생애 초기부터 나타나는 아동과 양육 자와의 상호작용으로 아동의 언어이전기 의사소통 능력의 발달을 보여주는 지표가 되며(Bruner, 1983) 아동은 차례맡기를 통해 언어 발달 및 이후 대화능력을 발달시킨다(Owens, 2005). 차례맡기는 일반 영유아의 초기 의사소통 능력을 평가에 사용되고 있으며(Gratier et al., 2015; Kim, Kim, \& Lee, 2012; Kwak, Kim, \& Hahn, 2004; Rutter \& Durkin, 1987), 청각장애 영유아에게도 의미있는 평가 지 표이다(Tait \& Wood, 1987). 또한 일반적으로 청각장애 아동의 말 지각 능력 평가는 부모설문에 의해 실시되었으나 Tait 비디오 분석 법은 청각적 인식을 비시각적 차례로 측정함으로써 아동의 듣기능 력에 따른 상호작용 행동을 직접 평가한다.

Tait 비디오 분석법에서 평가되는 세 지표는 와우이식 3년 이후
말지각 능력을 예측하며(Tait \& Lutman, 1997; Tait, Lutman, \& Robinson, 2000), 평가 지표를 검사자들 간 독립적으로 전사하여 분석한 결과, 높은 신뢰도를 나타내었다(Tait, Nikolopoulos, Lutman, Wilson, \& Wells, 2001; Tait, Nikolopoulos, Wells, \& White, 2007). Nikolopoulos, Archbold 그리고 Gregory (2005)는 청각장 애 영유아의 초기 의사소통 평가를 위해 The Nottingham Early Assessment Package (NEAP)를 제안하였으며 상호작용 평가로 Tait 비디오 분석법을 포함시켰다.

조기진단으로 어린 나이에 와우이식을 받은 청각장애 영유아들 의 언어 발달을 지속적으로 모니터링하기 위하여서는 언어이전기 에 나타나는 상호작용 능력의 평가부터 필요하다. 이는 언어이전기 의 상호작용 수준이 언어발달을 예측하는 변수로 보고되고 있기 때문이다. 그러나 대부분의 선행연구에서 사용한 평가 방법은 청 각장애의 특성이 반영되지 않았고, 분석에 많은 노력과 시간이 필 요하여 임상 현장에서 활용이 되지 못하고 있다. 따라서 청각장애 영유아의 특성에 적합하고 임상에서 간단하게 실시할 수 있으며, 언어발달을 예측할 수 있는 언어이전기의 상호작용 능력 평가가 필 요하다. Tait 비디오 분석법은 평가 시간이 짧고 분석이 용이하며 신뢰도가 높고 언어발달을 위한 예측 요인으로의 역할을 할 수 있 으며, 무엇보다 듣기에 따른 상호작용 반응을 직접 평가한다는 점 에서 청각장애 영유아의 상호작용 평가에 적합하다고 볼 수 있다. 따라서 본 연구에서는 Tait 비디오 분석법을 사용하여 와우이식 영 유아의 상호작용 행동을 차례맡기, 개시성, 청각적 인식의 세 변인 으로 평가하고 언어연령 및 생활연령을 일치시킨 일반 영유아와 비 교함으로써 이들의 상호작용 발달 특성을 살펴보고자 한다.

\section{연구 방법}

\section{연구대상}

본 연구는 서울 경기, 충남지역에 거주하는 와우이식을 받은 생 후 20-37개월 사이의 청각장애 영유아 9명, 이들과 언어연령을 일치 시킨 일반 영유아 9명, 생활연령을 일치시킨 일반 영유아 9명으로 총 27 명을 대상으로 하였으며 집단별 성별 분포는 각각 남자 4 명, 여자 5명이다. 와우이식 영유아집단(CI)은 선천성 심도 및 고심도 청각장애로 와우이식술 후 6개월 이상 경과되었으며 언어연령이 만3세 미만으로 한국형 덴버II검사(Shin, Han, Oh, Oh, \& Oh, 2002) 에서 언어발달영역을 제외한 모든 영역에서 정상발달 범위에 있으 며, 청각장애 외에 다른 감각, 인지 및 정서-행동 문제가 보고되지 않은 아동이다. 언어연령일치 집단과 생활연령일치 집단의 일반 영 유아들은 영유아 언어발달검사(SELSI; Kim, Kim, Yoon, \& Kim, 
Table 1. Participants characteristics $(\mathrm{N}=9)$

\begin{tabular}{lccc}
\hline Age $(\mathrm{mo})$ & Cl group & LA group & CA group \\
\hline CA & $29.67 \pm 6.164(20-37)$ & $19.22 \pm 4.684(14-30)$ & $29.22 \pm 6.438(19-36)$ \\
LA & $19.56 \pm 4.333(14-29)$ & $19.33 \pm 4.664(14-30)$ & - \\
CIA & $13.89 \pm 2.934(11-20)$ & - & - \\
\hline
\end{tabular}

Values are presented as mean $\pm S D$ (range).

$\mathrm{Cl}$ group= cochlear implant children; $\mathrm{LA}$ group = language age-matched children; $\mathrm{CA}$ group= chronological age-matched children; $C A=$ chronological age; $L A=$ language age measured with Sequenced of Language Scale for Infants(SELSI; Kim et al., 2003); $\mathrm{CIA}=$ age at cochlear implant.

2003)에서 언어전반 점수가 -1 SD 이상이고 한국형 덴버II검사의 모든 영역이 정상이며 감각, 인지 및 정서·행동 문제가 없다고 보고 된 아동이었다. 일반 영유아들은 Ling 6 검사의 6개음을 탐지할 수 있었으며 와우이식 영유아와 성별을 일치시켰다. 언어연령일치 집 단(LA)은 와우이식 영유아의 언어연령과 \pm 1 개월 이내로 일치시 켰으며, 생활연령일치 집단(CA) 또한 와우이식 영유아의 생활연령 과 \pm 1 개월 이내로 일치시켰다(Table 1).

와우이식 영유아 7 명은 양쪽 귀에, 2 명은 한쪽 귀에 인공와우를 착용하였다. 한쪽 귀에 인공와우를 착용한 영유아 중 한 명은 반대 쪽 귀에 보청기를 착용하였으며 나머지 한 명은 보청기를 착용하지 않았다. SELSI 언어연령에서 CI집단과 LA집단은 통계적으로 유의 한 차이가 없었으며 $\mathrm{CI}$ 집단과 $\mathrm{CA}$ 집단은 생활연령에서 통계적으로 유의한 차이가 없었다. CI집단의 배경정보는 Appendix 1과 같다.

CI집단의 평균 생활연령은 29.67 개월, 평균 언어연령은 19.56 개 월이며 평균 와우이식연령은 13.89 개월이다.

\section{연구절차}

실험은 연구자가 대상자의 가정 또는 언어치료실을 방문하여 아 동과 직접 놀이를 하며 상호작용을 유도하였다. 모든 대상자에게 자동차 놀이, 주방 놀이, 놀이터 놀이, 병원 놀이 장난감 세트를 동 일하게 제공하여 아동이 자유롭게 선택하도록 하고, 자연스럽게 상호작용을 촉진하였으며 그림책 보기는 모든 아동에게 시행하였 다. 대상자와의 상호작용 상황을 디지털 카메라(Samsung STWVLUUNV100HD)로 20-30분 녹화하였다. 상호작용하는 동안 대 상자의 양육자는 조금 떨어진 곳에서 상호작용을 관찰하였으며 녹 화가 끝난 후 수집된 상호작용 형태가 평소와 유사한지 확인하였 다. 상호작용 절차에 대하여는 Appendix 2에 수록하였다.

\section{자료분석}

수집한 20-30분의 녹화자료에서 상호작용이 연속되어 진행된 부분을 선택하여 Tait (1993)의 전사 방법에 따라 전사하였다. 총 50
개의 연속된 차례를 선정하여 (1) 차례맡기의 산출 형태를 발성 차 례맡기, 몸짓 차례맡기, 무반응으로 분류, (2) 개시성의 빈도를 분석 하고 이를 발성 개시성과 몸짓 개시성으로 분류, (3) 청각적 인식의 빈도를 분석하고 이를 비시각적 발성 차례, 비시각적 몸짓 차례로 분류하였다. 분석 방법은 Tait를 따랐고(Tait \& Wood, 1987; Tait, De Raeve, \& Nikolopoulos, 2007), 분류체계에 대한 설명과 분석 예시는 Appendixes 3 과 4 에 수록하였다.

\section{신뢰도 분석}

분석을 시작하기 전에 연구자들은 채점 기준을 충분히 숙지하고 연구에 포함되지 않았던 3명의 자료에 대해 전사와 분석을 연습하 여 분석의 일치도를 $90 \%$ 이상으로 일치시킨 후 자료 분석을 실시 하였다. 평가의 신뢰성 확보를 위해 언어치료학전공 대학원생 1 인 에게 채점기준을 교육 한 후 전체 자료의 $30 \%$ 에 대해 분석을 하게 하여 신뢰도를 평가하였다. 신뢰도는 일치된 반응수를 일치된 반 응수와 불일치 된 반응수를 합한 수로 나눈 후 100 을 곱하여 산출 하였다. 측정 결과, 발성 차례맡기는 $99.3 \%$, 몸짓 차례맡기는 $97.6 \%$, 발성 개시성은 $98.1 \%$, 몸짓 개시성은 $91.2 \%$, 비시각적 발성 차례는 $99.1 \%$, 비시각적 몸짓 차례는 $95.2 \%$, 무반응은 $94.1 \%$ 의 일치도를 보였다.

\section{통계 분석}

집단(CI, LA, CA)과 산출 형태(발성, 몸짓)에 따른 차례맡기, 개 시성, 청각적 인식의 차이를 알아보기 위하여 집단 간 요인과 집단 내 요인의 혼합분산분석을 실시하였으며 사후분석은 Tukey의 방 법을 사용하였다. CI집단과 LA집단의 언어연령에 따른 발성 차례 맡기, 몸짓 차례맡기, 발성 개시성, 비시각적 발성 차례에 대한 상관 을 알아보기 위하여 Pearson의 적률상관계수를 산출하였다. 통계 분석에 사용한 프로그램은 PASW ver. 18.0 (SPSS Inc., Chicago, IL, USA)였다.

\section{연구 결과}

\section{집단 간 차례맡기 빈도의 차이}

세 집단(CI, LA, CA)의 산출 형태(발성, 몸짓)에 따른 차례맡기 빈도의 평균 및 표준편차는 Table 2 와 같다. 총 50 차례 중 발성 차 례맡기 빈도는 CI집단이 평균 27.33회, LA집단이 평균 21.22회, CA 집단이 평균 39.11회로 나타났으며 몸짓 차례맡기 빈도는 CI집단 이 평균 19.78 회, LA집단이 평균 21.22회, CA집단이 평균 39.11 회로 나타났다. 
Table 2. Descriptive statistics of frequencies of turn-taking in groups ( $N=9$ )

\begin{tabular}{lccc}
\hline & Cl group & LA group & CA group \\
\hline Vocal turn-taking & $27.33 \pm 9.975$ & $21.22 \pm 9.311$ & $39.11 \pm 7.504$ \\
& $(11-37)$ & $(8-35)$ & $(24-50)$ \\
Gestural turn-taking & $19.78 \pm 9.576$ & $24.56 \pm 8.278$ & $9.44 \pm 7.401$ \\
& $(9-33)$ & $(13-40)$ & $(0-25)$ \\
No response & $3.00 \pm 2.646$ & $4.22 \pm 3.528$ & $1.44 \pm 1.509$ \\
& $(0-9)$ & $(0-12)$ & $(0-5)$ \\
\hline
\end{tabular}

Values are presented as mean $\pm \mathrm{SD}$ (range).

$\mathrm{Cl}$ group = cochlear implant; LA group = language age-matched children; CA group =chronological age-matched children.

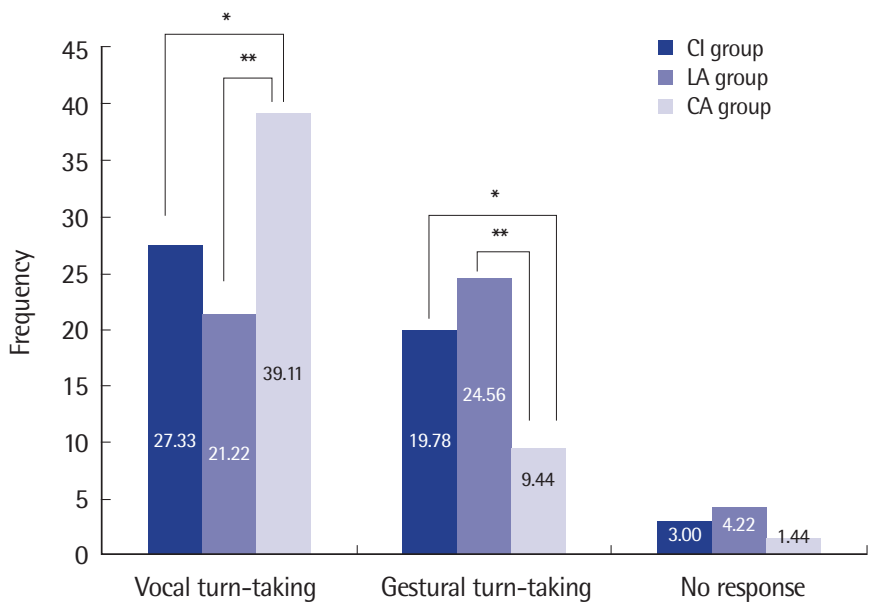

Figure 1. Mean of frequencies of turn-taking between groups. Cl group=cochlear implant; LA group = language age-matched children; CA group =chronological age-matched children. ${ }^{*} p<.05,{ }^{* *} p<.01$.

집단과 산출 형태에 대한 차례맡기 빈도의 차이를 보기 위한 분 산분석 결과, 산출 형태는 주효과가 유의하였으며 $\left(F_{(1,24)}=11.558\right.$, $p<.05)$, 집단과 산출 형태 간의 상호작용효과가 유의하게 나타났 다 $\left(F_{(2,24)}=8.537, p<.05\right)$. 산출 형태별로 집단 간 차이를 분석한 결 과, 발성 차례맡기 $\left(F_{(2,24)}=9.203, p<.01\right)$ 와 몸짓 차례맡기 $\left(F_{(2,24)}=\right.$ $7.492, p<.01)$ 빈도에서 세 집단 간에 통계적으로 유의한 차이가 나 타났다. Tukey 사후분석을 실시한 결과, $\mathrm{CI}$ 집단과 LA집단은 발성 차례맡기와 몸짓 차례맡기 빈도에서 CA집단과 유의한 차이를 보 였다(Figure 1).

\section{집단 간 개시성 빈도의 차이}

$\mathrm{CI}$ 집단과 $\mathrm{LA}$ 집단 및 $\mathrm{CA}$ 집단이 나타낸 산출 형태에 따른 개시성 빈도의 평균 및 표준편차는 Table 3 과 같다. 발성과 몸짓을 합한 개 시성 빈도는 CI집단이 평균 17.33회, LA집단이 평균 14.22회, CA집 단이 평균 20.78회로 나타났다. 발성 개시성 빈도는 CI집단이 평균 12.56 회, LA집단이 평균 8.44회, CA집단이 평균 18.22회로 나타났
Table 3. Descriptive statistics of frequencies of autonomy in groups ( $N=9)$

\begin{tabular}{lccc}
\hline & Cl group & LA group & CA group \\
\hline Autonomy (vocal + & $17.33 \pm 6.021$ & $14.22 \pm 2.819$ & $20.78 \pm 4.147$ \\
gestural) & $(6-24)$ & $(11-19)$ & $(14-26)$ \\
Vocal autonomy & $12.56 \pm 6.327$ & $8.44 \pm 4.531$ & $18.22 \pm 4.738$ \\
& $(2-21)$ & $(2-17)$ & $(9-25)$ \\
Gestural autonomy & $4.78 \pm 2.279$ & $5.78 \pm 3.270$ & $2.56 \pm 1.810$ \\
& $(2-8)$ & $(1-11)$ & $(0-5)$ \\
\hline
\end{tabular}

Values are presented as mean $\pm S D$ (range).

$\mathrm{Cl}$ group = cochlear implant; LA group = language age-matched children; $\mathrm{CA}$ group = chronological age-matched children.

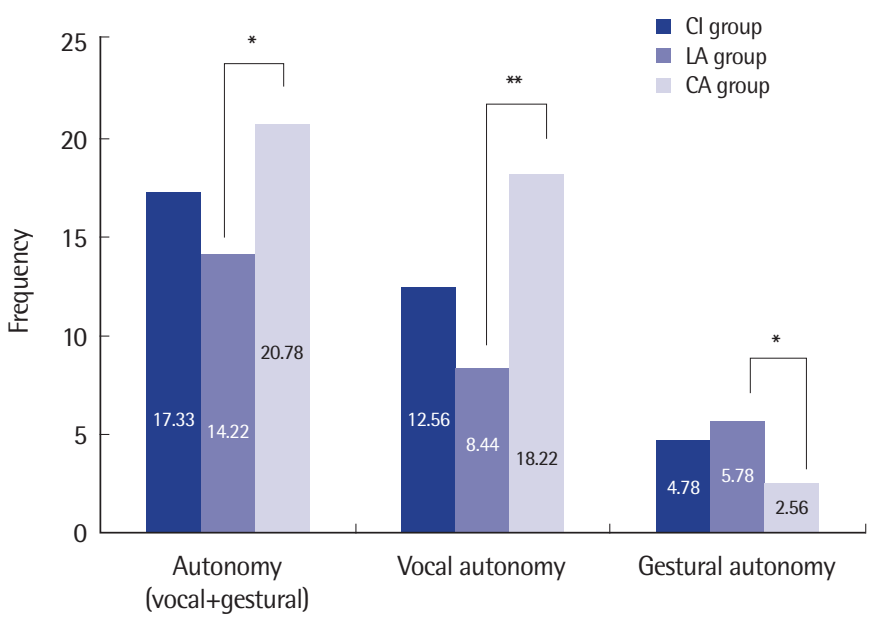

Figure 2. Mean of frequencies of autonomy between groups. $\mathrm{Cl}$ group=cochlear implant; LA group= language age-matched children; $C A$ group = chronological agematched children. ${ }^{*} p<.05,{ }^{* *} p<.01$.

으며 몸짓 차례맡기 빈도는 CI집단이 평균 4.78회, LA집단이 평균 5.78 회, CA집단이 평균 2.56회로 나타났다.

집단과산출형태에 대한 개시성 빈도의 차이를 보기 위하여 분산 분석을 실시한 결과, 집단 $\left(F_{(2,24)}=4.729, p<.05\right)$ 과 산출 형태 $\left(F_{(1,24)}=\right.$ $42.927, p<.001)$ 의 차이가 유의하였으며, 산출 형태와 집단 간 상호 작용효과가 유의하게 나타났다 $\left(F_{(2,24)}=8.102, p<.01\right)$. 산출 형태별 로 집단 간 차이를 분석한 결과, 발성 개시성 $\left(F_{(2,24)}=7.841, p<.01\right)$ 와 몸짓 개시성 $\left(F_{(2,24)}=3.832, p<.05\right)$ 빈도에서 세 집단 간에 통계 적으로 유의한 차이가 있었다. Turkey 사후분석을 실시한 결과, CI 집단은 LA집단 및 CA집단과 유의한 차이를 보이지 않았으며 LA집 단은 발성과 몸짓을 합한 개시성, 발성 개시성, 몸짓 개시성 빈도에 서 CA집단과 유의한차이를 보였다(Figure 2).

\section{집단 간 청각적 인식 빈도의 차이}

CI집단과 LA집단 및 CA집단이 나타낸 산출 형태에 따른 비시각 적 차례 빈도의 평균 및 표준편차는 Table 4 와 같다. 발성과 몸짓을 
Table 4. Descriptive statistics of non-looking turns in groups $(\mathrm{N}=9)$

\begin{tabular}{lccc}
\hline & Cl group & LA group & CA group \\
\hline Non-looking turn (vocal + & $12.22 \pm 5.932$ & $9.33 \pm 4.717$ & $20.56 \pm 5.102$ \\
gestural) & $(2-21)$ & $(2-17)$ & $(12-27)$ \\
Non-looking vocal turn & $8.56 \pm 5.812$ & $6.33 \pm 5.050$ & $18.33 \pm 5.937$ \\
& $(0-19)$ & $(0-15)$ & $(7-27)$ \\
Non-looking gestural turn & $3.67 \pm 3.741$ & $3.00 \pm 1.581$ & $2.22 \pm 1.787$ \\
& $(0-11)$ & $(1-6)$ & $(0-5)$ \\
\hline
\end{tabular}

Values are presented as mean $\pm \mathrm{SD}$ (range).

$\mathrm{Cl}$ group=cochlear implant; LA group=language age-matched children; $\mathrm{CA}$ group= chronological age-matched children.

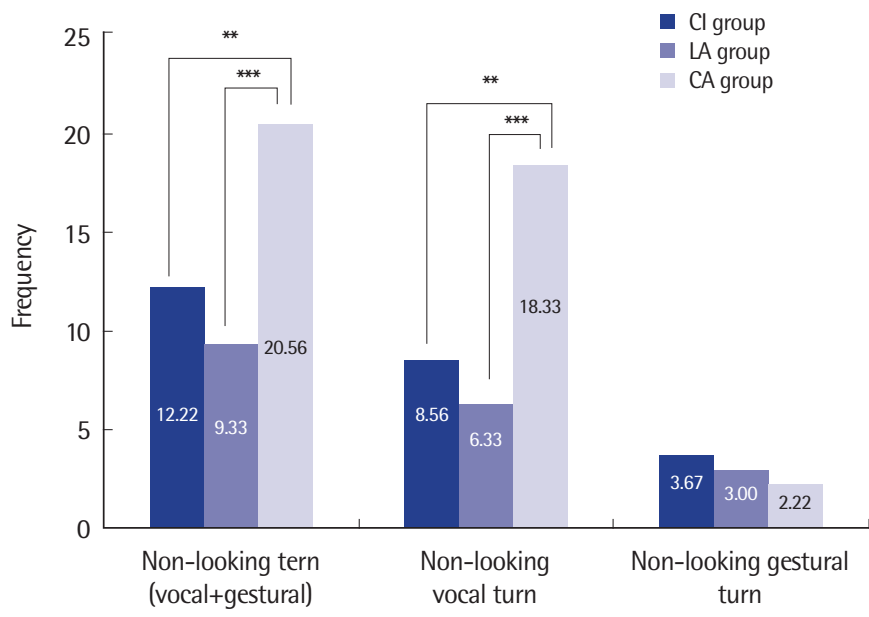

Figure 3. Mean of frequencies of non-looking turns between groups. $\mathrm{Cl}$ group= cochlear implant; $L A$ group =language age-matched children; $C A$ group $=$ chronological age-matched children. ${ }^{* *} p<.01,{ }^{* * *} p<.001$.

합한 비시각적 차례 빈도는 CI집단이 평균 12.22회, LA집단이 평균 9.33회, CA집단이 평균 20.56회로 나타났다. 비시각적 발성 차례 빈 도는 CI집단이 평균 8.56회, $\mathrm{LA}$ 집단이 평균 6.33회, $\mathrm{CA}$ 집단이 평균 18.33 회로 나타났으며 비시각적 몸짓 차례 빈도는 CI집단이 평균 3.67회, LA집단이 평균 3.00회, CA집단이 평균 2.22회로 나타났다.

집단과 산출 형태에 대한 비시각적 차례 빈도의 차이를 보기 위 하여 분산분석을 실시한 결과, 집단 $\left(F_{(2,24)}=10.983, p<.001\right)$ 과 산출 형태 $\left(F_{(1,24)}=36.759, p<.001\right)$ 의 차이가 유의하였으며, 산출 형태와 집단 간 상호작용효과가 유의하게 나타났다 $\left(F_{(2,24)}=9.052, p<.01\right)$. 산출 형태별로 집단 간 차이를 분석한 결과, 비시각적 발성 차례 빈 도는세 집단간에 통계적으로 유의한차이가 있었으나 $\left(F_{(2,24)}=11.641\right.$, $p<.001)$, 비시각적 몸짓 차례 빈도는 통계적으로 유의한 차이를 보 이지 않았다. Tukey 사후분석을 실시한 결과, CI집단과 LA집단은 발성과 몸짓을 합한 비시각적 차례, 비시각적 발성 차례에서 CA집 단과 유의한 차이를 보였다(Figure 3).

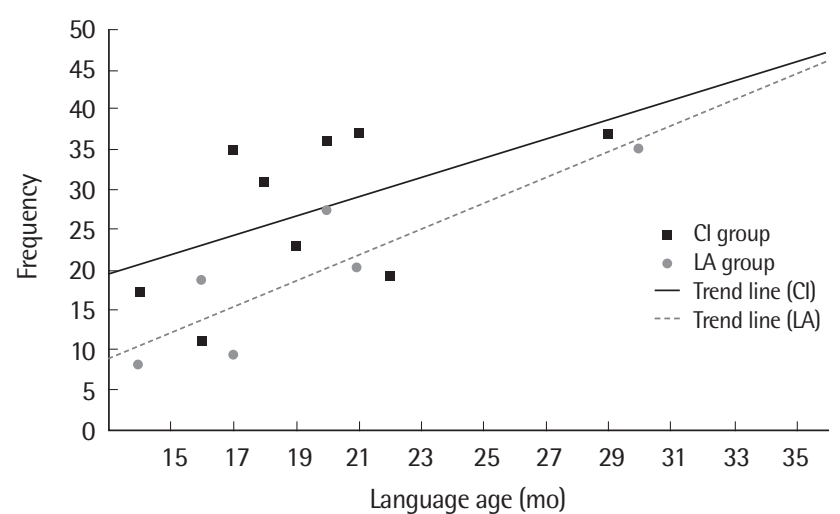

Figure 4. Scatter plot of frequency of vocal turn-taking regarding language age in $\mathrm{Cl}$ and LA groups. Cl group= cochlear implant; LA group = language agematched children.

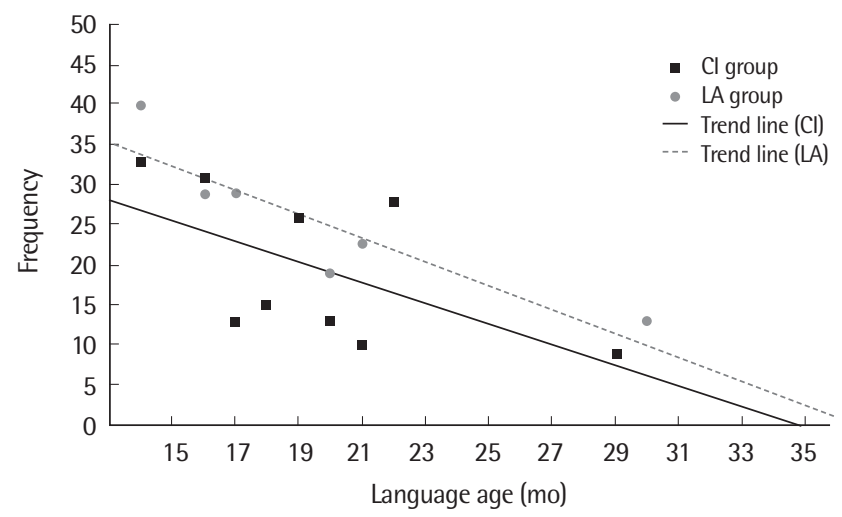

Figure 5. Scatter plot of frequency of gestural turn-taking regarding language age in $\mathrm{Cl}$ and $\mathrm{LA}$ groups. $\mathrm{Cl}$ group= cochlear implant; LA group = language agematched children.

\section{언어연령에 따른 차례맡기, 개시성, 청각적 인식의 상관}

CI집단과 LA집단의 언어연령에 따른 발성 차례맡기, 발성 개시 성, 비시각적 발성 차례의 상관관계를 Pearson의 적률상관계수로 분석하였다. 언어연령과 발성 차례맡기 빈도는 두 집단 모두 정적 상관관계를 보였고(CI $r=.52$, LA $r=.79 ; p<.05)$, 언어연령과 몸짓 차례맡기 빈도는 두 집단 모두 부적 상관관계를 보였다(CI $r=.-58$, LA $r=-.84 ; p<.01$ ) (Figures 4,5$)$. 언어연령과 발성 개시성 빈도는 두 집단 모두 유의한 정적 상관관계를 보였다 $(\mathrm{CI} r=.79, p<.05 ; \mathrm{LA}$ $r=.87, p<.01$ ) (Figure 6). 언어연령과 비시각적 발성 차례 빈도는 두 집단 모두 유의한 정적 상관관계를 보였다 $(\mathrm{CI} r=.68, p<.05 ; \mathrm{LA}$ $r=.84, p<.01$ ) (Figure 7).

\section{논의 및 결론}

본 연구는 와우이식술 후 6개월 이상 경과한 와우이식 영유아집 


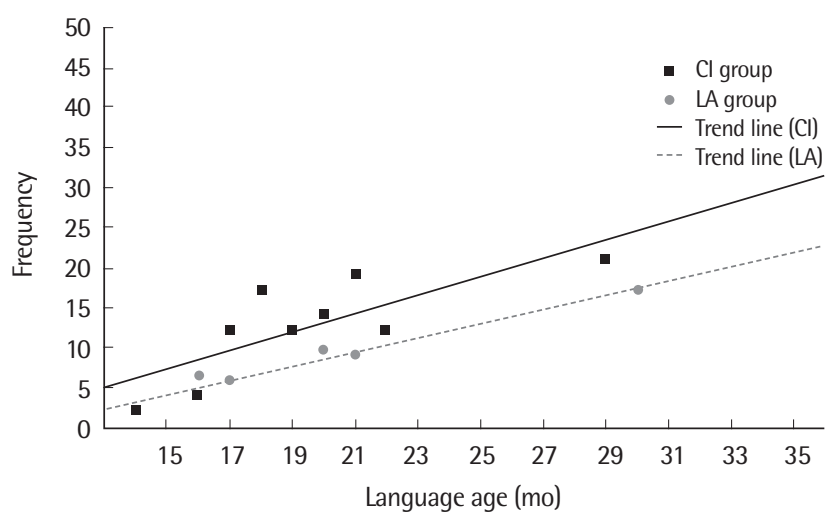

Figure 6. Scatter plot of frequency of vocal autonomy regarding language age in $\mathrm{Cl}$ and LA groups. Cl group = cochlear implant; LA group = language agematched children.

단(CI)의 상호작용 행동을 Tait 분석방법에 따라 차례맡기, 개시성, 청각적 인식의 세 지표로 평가하고 이를 언어연령을 일치시킨 일반 영유아집단(LA) 및 생활연령을 일치시킨 일반 영유아집단(CA)과 비교하여 와우이식 영유아의 상호작용의 발달 패턴을 살펴보는 것 을 목적으로 하였다.

연구 결과, $\mathrm{CI}$ 집단은 차례맡기의 빈도에서 발성과 몸짓 모두 LA 집단과 유의한 차이가 없었으나 CA집단과는 유의한 차이를 보였 다. 즉, $\mathrm{CI}$ 집단은 차례맡기에서 생활연령이 같은 아동보다 유의하 게 발성은 적고 몸짓을 많이 사용하였으나 언어연령이 같은 아동과 는 발성과 몸짓의 사용 빈도가 차이가 없었다. 이는 Tait, de Raeve 등(2007)의 연구에서 8-11개월에 와우이식술을 한 CI집단이 와우 이식술 1년 후 CA집단보다 발성은 적고 몸짓은 더 많이 산출한다 는 결과와도 일치한다. Sung 등(2010)의 연구에서도 CI와 LA집단 이 CA집단보다 의사소통의도 산출 형태에서 몸짓을 더 많이 사용 한 것으로 보고한 바 있다. 의사소통의도 발달에 대한 선행연구 (Nicholas et al., 1994; Yeon, 2001)에서 CI집단은 CA집단보다 의사 소통의도의 산출 빈도가 적고 LA집단과는 비슷하거나 높은 것으 로 나타났다. Rinaldi 등(2013)의 연구에서는 2세 이전에 CI이식을 한 청각장애 영유아를 대상으로 부모 설문을 통해 차례맡기의 상 호작용능력에서 CI집단이 CA집단보다 늦다고 보고 하였다. 선행 연구들에서 사용된 언어이전기의 상호작용 능력에 대한 평가방법 이 다양하나, $\mathrm{CI}$ 집단의 상호작용이 LA집단과는 비슷하게, $\mathrm{CA}$ 집단 보다는 느리게 발달한다는 것이 공통적으로 나타난 특성이다.

비시각적 발성 차례 빈도로 측정한 청각적 인식에서 $\mathrm{CI}$ 집단은 $\mathrm{CA}$ 집단보다는 빈도가 낮았으나 LA집단과는 차이가 없었다. 즉, 와우이 식 아동이 앞선 대화 상대자의 말을 듣고 반응하는 것은 언어연령이 같은 일반 아동과 동일한 수준이었다는 의미이다. 따라서 와우이식

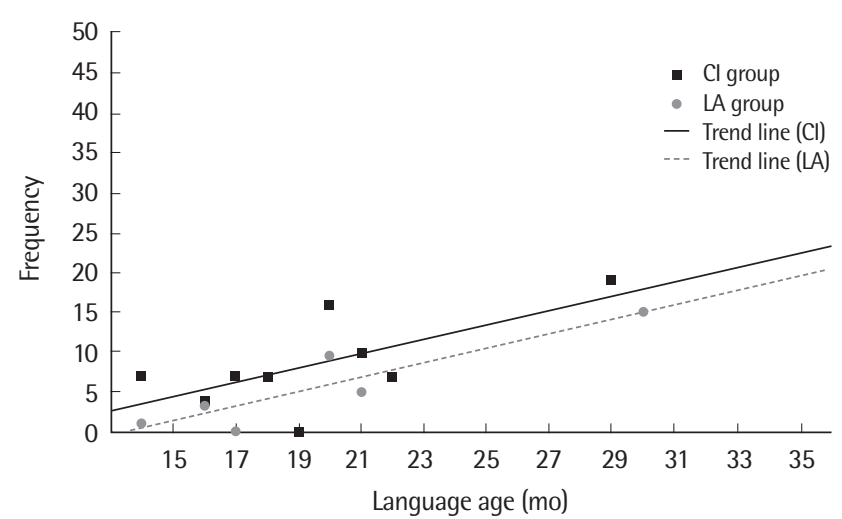

Figure 7. Scatter plot of frequency of non-looking vocal turns regarding language age in $\mathrm{Cl}$ and $\mathrm{LA}$ groups. $\mathrm{Cl}$ group = cochlear implant; $\mathrm{LA}$ group= language age-matched children.

아동의 청각적 인식은 언어연령 수준에 따라 결정됨을 알 수 있었다. 비시각적 발성 차례 빈도는 일반 아동에서도 연령에 따라 차이가 있 었다. CI집단과 LA집단은 유의한 차이가 없는 것으로 보아와우이식 아동은 와우이식 이후 청각적 입력이 제공됨으로써 언어가 발달하 게 되었고 언어발달 연령에 맞게 상호작용을 하는 것으로 추정된다.

다른 지표와 다르게 총 개시성과 발성 및 몸짓 개시성에서 $\mathrm{CI}$ 집 단과 CA집단은 유의한 차이가 없었다. 반면 LA집단은 총 개시성, 발성 개시성에서 CA집단보다 유의하게 낮고 몸짓 개시성에서 CA 집단보다 유의하게 높았다. Nicholas 등(1994)의 연구에서는 청각 장애 영유아집단이상호작용 시 의사소통 기능 중 요구하기(request), 주장하기(protest), 승인하기(acknowledge)에서 생활연령일치 집단 과 차이를 보이지 않아 청각장애 영유아의 상호작용 능력이 전반적 발달수준 및 생활연령과 관련이 있다고 보고한 바 있다. 개시성을 청각적 능력보다 아동의 발달수준 및 생활연령과 연관지어 본다면, CI집단은 LA집단보다 평균 생활연령이 10 개월 정도 높았고 이식 수술 전 평가에서 듣기와 언어발달을 제외한 다른 발달영역의 문제 나 중복장애가 없다는 것이 확인된 아동이었다. 또한 본 연구의 연 구대상자 선정 시 일반발달검사를 실시하여 이를 다시 한 번 확인 하였다. 따라서 개시성은 언어수준보다 전반적인 발달수준에 영향 을 받아 $\mathrm{CI}$ 집단은 $\mathrm{CA}$ 집단과는 비슷한 수준으로, $\mathrm{LA}$ 집단보다는 좀 더 적극적으로 상호작용을 개시했을 것으로 추측할수 있다.

$\mathrm{CI}$ 집단과 LA집단의 언어연령에 따른 차례맡기 유형, 발성 개시 성, 비시각적 발성 차례 빈도의 관계를 보면, 두 집단은 언어연령에 따라 서로 같은 경향을 보이고 있어서 유사한 발달 패턴을 보이는 것을 알 수 있다. 이들은 연령이 증가함에 따라 상호작용 시 몸짓이 줄어들고 점점 발성적으로 되어 가며 상호작용 개시가 많아져 적극 적인 의사소통자가 될 것으로 기대된다. 
이상의 연구결과를 종합하여 볼 때, 와우이식 영유아의 상호작 용 평가에서 차례맡기로 본 상호작용 행동은 발달적으로는 지체되 나 언어발달 수준과 함께 한다는 것을 알 수 있다. Sung 등(2010)의 연구에서도 와우이식을 받은 영유아들은 엄마와의 상호작용 시 자 신들의 언어발달 연령에 맞는 의사소통의도의 발달을 나타내었다.

와우이식 아동의 상호작용 행동 발달은 일반발달 과정과 유사 하나 또래 집단에 비하여 발달적 지체가 나타나고 있으므로 이들 과의 차이를 줄이기 위한 방법이 요구된다. Cejas, Barker, Quittner 그리고 Niparko (2004)는 와우이식 영유아의 언어연령이 높을수 록 높은 수준의 공동 참여하기를 통한 사회적 상호작용의 참여가 가능하므로 이들의 언어연령을 높이는 것이 중요하다고 보고한 바 있다. 본 연구결과에서도 언어연령과 발성 차례맡기, 발성 개시성, 비시각적 발성 차례가 유의한 정적 상관이 나타나는 것으로 보아 언어연령이 높을수록 상호작용이 원활해지고 이는 다시 언어발달 을 촉진하게 될 것이다. 와우이식 아동의 언어연령을 높이는 것은 결국 조기진단 및 조기중재를 통하여 실현될 수 있다. Fulcher, Purcell, Baker 그리고 Munro (2012)는 조기진단 후 와우이식 혹은 보 청기를 착용하여 청각구어적 방법으로 조기중재를 받은 아동들이 3 세가 되었을 때 대상자의 대부분이 또래 아동의 언어발달 수준에 속하게 되었다고 보고하였다. 고심도 청각장애 영유아의 조기진단 이 이루어지고 와우이식을 통해 청각적 자극이 가능한 빨리 입력 되어야 하며 조기중재를 받음으로써 언어발달을 이루어 생활연령 과 언어연령의 차이를 줄이는 것이 일반발달 경로를 따라 또래 아 동의 발달에 빨리 근접할 수 있을 것이다.

신생아 청각선별검사가 확산되고 와우이식 연령이 12 개월 이하 로 낮아지고 있는 현 시점에서 청각장애 영유아의 구어 발달 이전 의 상호작용 과정에서 나타나는 초기 의사소통 능력에 대한 평가 의 필요성이 커지고 있다. 본 연구는 Tait 비디오 분석법으로 청각 장애 영유아의 상호작용을 평가하였고 이들의 의사소통 발달을 모 니터링 하는 방법으로 제안한다.

본 연구에서는 의사소통행동의 산출 형태를 발성과 몸짓으로만 분류하였으나, 대상아동의 경우 이미 구어 사용이 나타나는 아동 이 있었다. 또한 개시성과 청각적 인식에 대해 산출 여부만 분석하 였고 산출 유형에 대한 질적인 분석이 이루어지지 않았다. 산출 유 형을 보다 세분화하지 못한 것은 본 연구의 한계이며 후속 연구에 서 이루어지기를 기대한다

\section{REFERENCES}

Archbold, S., Lutman, M., \& Marshal, D. (1995). Categories of auditory per- formance. Annals of Otology, Rhinology \& Laryngology, 104(S66), 312-314. Bruner, J. (1983). Child's talk: learning to use language. New York: W. W. Norton.

Cejas, I., Barker, D. H., Quittner, A. L., \& Niparko, J. K. (2014). Development of joint engagement in young deaf and hearing children: effects of chronological age and language skills. Journal of Speech, Language, and Hearing Research, 57, 1831-1841.

Fulcher, A., Purcell, A. A., Baker, E., \& Munro, N. (2012). Listen up: children with early identified hearing loss achieve age-appropriate speech/language outcomes by 3 years-of-age. International Journal of Pediatric Otorhinolaryngology, 76, 1785-1794.

Gratier, M., Devouche, E., Guellai, B., Infanti, R., Yilmaz, E., \& Parlato-Oliveira, E. (2015). Early development of turn-taking in vocal interaction between mothers and infants. Frontier in Psychology, 6, 236-245.

Guerzoni, L., Murri, A., Fabrizi, E., Nicastri, M., Mancini, P., \& Cuda, D. (2015). Social conversational skills development in early implanted children. Laryngoscope. Advanced online publication. http://dx.doi.org/10.1002/lary.25809.

Hong, G. H., \& Kim, Y. T. (2005). A longitudinal study of predictors for expressive vocabulary development of the late-talkers. Korean Journal of Communication Disorders, 10, 1-24.

Kane, M. O. L., Schopmeyer, B., Mellon, N. K., Wang, N. Y., \& Niparko, J. K. (2004). Prelinguistic communication and subsequent language acquisition in children with cochlear implants. Archives of Otolaryngology-Head \& Neck Surgery, 130, 619-623.

Kim, M. S., Kim, E. H., \& Lee, Y. J. (2012). One year longitudinal study of the relationship between infants' turn-taking and vocabulary development. Journal of the Korean Home Economics Association, 50, 75-84.

Kim, Y. T., Kim, K. H., Yoon, H. R., \& Kim, H. S. (2003). Sequenced Language Scale for Infants (SELSI). Seoul: Special Education Publishing.

Kwak, K., Kim, M., \& Hahn, E. J. (2004). The interrelationship of infant-mother interaction and early social communication skills. Korean Journal of Child Studies, 25, 111-128.

Nicholas, J. G. (1994). Sensory aid use and the development of communicative function. The Volta Review, 96, 181-198.

Nicholas, J. G., \& Geers, A. E. (2006). Effects of early auditory experience on the spoken language of deaf children at 3 years of age. Ear and Hearing, 27, 286-298

Nicholas, J. G., Geers, A. E., \& Kozak, V. (1994). Development of communicative function in young hearing-impaired and normally hearing children. The Volta Review, 96, 113-135. 
Nikolopoulos, T. P., Archbold, S. M., \& Gregory, S. (2005). Young deaf children with hearing aids or cochlear implants: early assessment package for monitoring progress. International Journal of Pediatric Otorhinolaryngology, 69, 175-186.

Owens, R. E. (2005). Language development: an introduction (6th ed., S. B. Lee \& H. R. Lee, Trans.). Seoul: Sigmapress.

Quittner, A. L., Leibach, P., \& Marciel, K. (2004). The impact of cochlear implants on young deaf children: new methods to assess cognitive and behavioral development. Archives of Otolaryngology-Head \& Neck Surgery, 130, 547-554.

Rinaldi, P., Baruffaldi, F., Burdo, S., \& Caselli, M. C. (2013). Linguistic and pragmatic skills in toddlers with cochlear implant. International Journal of Language \& Communication Disorders, 48, 715-725.

Rutter, D. R., \& Durkin, K. (1987). Turn-taking in mother-infant interaction: an examination of vocalizations and gaze. Developmental Psychology, 23, 54-61.

Shin, H. S., Han, K., J., Oh, G. S., Oh, J. J., \& Oh, M. N. (2002). Korean-Denver Developmental Screening Test II. Seoul: Hyunmoon.

Spencer, P. E. (1993). Communication behaviors of infants with hearing loss and their hearing mothers. Journal of Speech, Language, and Hearing Research, 36, 311-321.

Sung, Y. J., Yoon, M. S., \& Hong, G. H. (2010). Analysis of communication intention of children with cochlear implant. Korean Journal of Communication Disorders, 15, 205-219.

Tait, D. M. (1993). Video analysis: a method of assessing changes in preverbal and early linguistic communication after cochlear implantation. Ear and Hearing, 14, 378-389.

Tait, D. M., \& Wood, D. J. (1987). From communication to speech in deaf children. Child Language Teaching and Therapy, 3, 1-17.
Tait, M. E., Nikolopoulos, T. P., Lutman, M. E., Wilson, D., \& Wells, P. (2001). Video analysis of pre-verbal communication behaviours: use and reliability. Deafness \& Education International, 3, 38-43.

Tait, M. E., Nikolopoulos, T. P., Wells, P., \& White, A. (2007). The use and reliability of Tait video analysis in assessing preverbal language skills in profoundly deaf and normally hearing children under 12 months of age. International Journal of Pediatric Otorhinolaryngology, 71, 1377-1382.

Tait, M., \& Lutman, M. E. (1997). The predictive value of measures of preverbal communicative behaviors in young deaf children with cochlear implants. Ear and Hearing, 18, 472-478.

Tait, M., De Raeve, L., \& Nikolopoulos, T. P. (2007). Deaf children with cochlear implants before the age of 1 year: comparison of preverbal communication with normally hearing children. International Journal of Pediatric Otorhinolaryngology, 71, 1605-1611.

Tait, M., Lutman, M. E., \& Robinson, K. (2000). Preimplant measures of preverbal communicative behavior as predictors of cochlear implant outcomes in children. Ear and Hearing, 21, 18-24.

Yeon, S. J. (2001). Communicative intentions of hearing-impaired and normally hearing children at 3 years of age (Master's thesis). Ewha Womans University, Seoul, Korea.

Yoon, M. S. (2010). Validity of communication assessment protocol of early intervention for children with hearing impairment. Journal of Speech-Language \& Hearing Disorders, 19, 211-232.

Yoon, M. S., \& Choi. E. A. (2010). Early intervention for children with hearing impairment: assessment of communication abilities. Korean Journal of Communication Disorders, 15, 1-19.

Zimmerman-Phillips, S., Robbins, A., \& Osberger, M. (2001). Meaningful Auditory Integration Scale (ITMAIS) for Infants and Toddlers. Sylmar: Advanced Bionics Corporation. 
Appendix 1. 와우이식 영유아집단의 배경 정보

\begin{tabular}{|c|c|c|c|c|c|c|c|c|c|c|c|c|}
\hline \multirow{2}{*}{ 대상자 } & \multirow{2}{*}{ 성별 } & \multirow{2}{*}{$\begin{array}{l}\text { 생활 연령 } \\
\text { (개월) }\end{array}$} & \multirow{2}{*}{$\begin{array}{l}\text { 언어 연령 } \\
\text { (개월) }\end{array}$} & \multicolumn{2}{|c|}{$\begin{array}{l}\text { 수술 전 } \\
\text { 청력수준 }\end{array}$} & \multicolumn{2}{|c|}{$\begin{array}{c}\text { 와우이식술 받은 귀 } \\
\text { (보정청력, } \mathrm{dB} \text { ) }\end{array}$} & \multirow{2}{*}{$\begin{array}{c}\text { 보청기 } \\
\text { 착용유무 } \\
\text { (보정청력, } \\
\mathrm{dB} \text { ) }\end{array}$} & \multicolumn{2}{|c|}{$\begin{array}{c}\text { 와우이식 수술시기 } \\
\text { (개월) }\end{array}$} & \multirow{2}{*}{$\begin{array}{l}\text { CAP } \\
\text { score }\end{array}$} & \multirow{2}{*}{$\begin{array}{l}\text { IT-MAIS } \\
\text { score }\end{array}$} \\
\hline & & & & $\mathrm{R}$ & L & $\mathrm{R}$ & $L$ & & $\mathrm{R}$ & $\mathrm{L}$ & & \\
\hline 1 & 여 & 20 & 14 & 90 & 90 & 25 & - & 무 & 13 & - & 4 & 26 \\
\hline 2 & 여 & 22 & 20 & 110 & 110 & 30 & 30 & - & 12 & 18 & 5 & 37 \\
\hline 3 & 남 & 25 & 21 & 100 & 100 & 20 & 20 & - & 17 & 17 & 5 & 38 \\
\hline 4 & 남 & 28 & 16 & 100 & 100 & $30-40$ & 40 & - & 12 & 25 & 4 & 31 \\
\hline 5 & 남 & 32 & 18 & 100 & 100 & 30 & 30 & - & 12 & 18 & 5 & 33 \\
\hline 6 & 여 & 33 & 17 & $N R$ & NR & - & - & - & 15 & 22 & 4 & 31 \\
\hline 7 & 여 & 35 & 19 & 130 & 110 & $25-30$ & $25-30$ & - & 34 & 11 & 4 & 31 \\
\hline 8 & 여 & 35 & 29 & 90 & 100 & - & - & - & 13 & 23 & 7 & 40 \\
\hline 9 & 남 & 37 & 22 & 100 & 90 & - & 20 & $\mathrm{R}$ & - & 20 & 5 & 33 \\
\hline
\end{tabular}

언어연령=SELSI (Kim, Kim, Yoon, \& Kim, 2003) 검사결과 언어전반 등가연령; CAP=Categories of Auditory Performance (Archbold, Lutman, \& Marshal, 1995); IT-MAIS=Infant-Toddler Meaningful Auditory Integration Scale (Zimmerman-Phillips, Robbins, \& Osberger, 2001).

Appendix 2. 상호작용 절차 및 유의점

\begin{tabular}{ll}
\hline 상호작용 절차 & 1. 연구자는 녹화를 시작하기 전에 아동과 함께 상호작용하며 아동이 연구자에게 익숙해지도록 한다. \\
& 2. 연구자는 아동에게 자동차 놀이, 주방 놀이, 놀이터 놀이, 병원 놀이를 제시하여 아동이 선택하도록 한다. \\
& 3. 연구자는 아동이 선택한 장난감 외 다른 장난감을 뒤쪽으로 치운 후 아동과 사선으로 앉아 녹화를 시작하고 아동과 자연스럽게 상호작용한다. \\
& 4. 첫 번째 놀이가 끝난 후 모든 아동에게 그림책을 제시하여 그림책을 보며 상호작용한다. \\
& 5. 20-30분 정도 녹화를 한 후 아동의 양육자에게 아동의 상호작용 형태가 평소와 유사한 지 확인한다. \\
유의점 & 1. 연구자가 아동에게 질문을 할 때는 가능한 개방형 질문으로 한다. \\
2. 연구자는 아동이 놀이에만 집중하지 않도록 상호작용을 촉진한다. \\
3. 연구자는 아동에게 시각적 단서를 줄 수 있는 손짓이나 몸짓을 통제한다. \\
4. 연구자는 아동의 언어 수준에 맞게 발화 길이를 조절한다. \\
5. 연구자의 차례가 끝나면 아동의 차례를 위해 3초의 쉼을 남겨둔다. \\
6. 아동이 원하는 장난감으로 상호작용을 하되 선택ㄱ한 장난감 외 다른 장난감은 뒤쪽으로 치워 상호작용하는 과정에서 산만해지지 않도록 한다. \\
아동이 다른 장난감놀이를 원할 때는 언제든 교체해준다.
\end{tabular}


Appendix 3. Tait 비디오 분석법의 분류 체계 설명

\begin{tabular}{|c|c|}
\hline 구분 & 설명 \\
\hline 차례맡기(turn-taking) & $\begin{array}{l}\text { 아동이 의사소통 할 기회를 차례(turn)라고 하며 차례맡기는 아동과 연구자의 상호작용 시 차례를 주고 받는 것. 아동과 연구자 중 } \\
\text { 아무나 차례를 시작할 수 있고 아동은 연구자의 차례를 방해하여 아동의 차례를 시작할 수 있음. 발성차례맡기(vocal turn-taking), } \\
\text { 몸짓 차례맡기(gestural turn-taking), 무반응(no response)으로 분류함. } \\
\text { 가. 발성 차례맡기(vocal turn-taking): 발성, 발성+몸짓, 말(Verbal), 말+몸짓으로 산출되는 반응. } \\
\text { 나. 몸짓 차례맡기(gestural turn-taking): 발성을 동반하지 않고 몸짓으로만 반응하는 것. 예를 들면 의사소통적인 몸짓(예: 가리 } \\
\quad \text { 키기, 보여주기, 건네주기, 고개 끄덕이기, 고개 가로젓기, 손 흔들기, 어깨 으쓱하기), 연구자의 요구에 대한 반응, 연구자가 } \\
\quad \text { 제시하는 것을 바라보는 시선, 사회적 미소, 연구자와의 눈맞춤(eye contact)이 포함됨. } \\
\text { 다. 무반응(no response): 연구자의 차례가 끝난 후 아동이 3초 이상 아무 반응을 보이지 않는 것. 예를 들면 연구자가 아동에게 } \\
\quad \text { 차례를 주었을 때 아동이 놀이에 집중하여 연구자의 메시지에 반응하지 않는 것. }\end{array}$ \\
\hline 개시성(autonomy) & $\begin{array}{l}\text { 아동과 연구자의 상호작용 시 앞선 연구자의 차례에서 예상하지 못한 것을 아동이 자신의 차례에서 제시하는 것. 예를 들면 새로운 } \\
\text { 정보를 제시하거나 추가하기, 반대하기, 주장하기, 속이기, 놀리기, 질문하기, 주제 바꾸기가 있으며 발성을 동반하는 경우 발성 } \\
\text { 개시성(vocal autonomy), 몸짓으로 표현하는 경우 몸짓 개시성(gestural autonomy)으로 분류함. }\end{array}$ \\
\hline 청각적 인식(auditory awareness) & $\begin{array}{l}\text { 아동과 연구자의 상호작용 시 아동이 청각적 단서만 듣고 반응하는 것으로 비시각적 차례(non-looking turn)로 측정함. 비시각적 } \\
\text { 차례는 앞 선 연구자의 차례에서 시각적 단서 없이 청각적으로만 듣고 아동이 자신의 차례에서 반응하는 것. 발성을 동반하는 경 } \\
\text { 우 비시각적 발성 차례(non-looking vocal turn), 몸짓으로만 표현하는 경우 비시각적 몸짓 차례(non-looking gestural turn)로 } \\
\text { 분류함. }\end{array}$ \\
\hline
\end{tabular}

Appendix 4. Tait 비디오 분석법의 분석 방법에 따른 상호작용의 전사

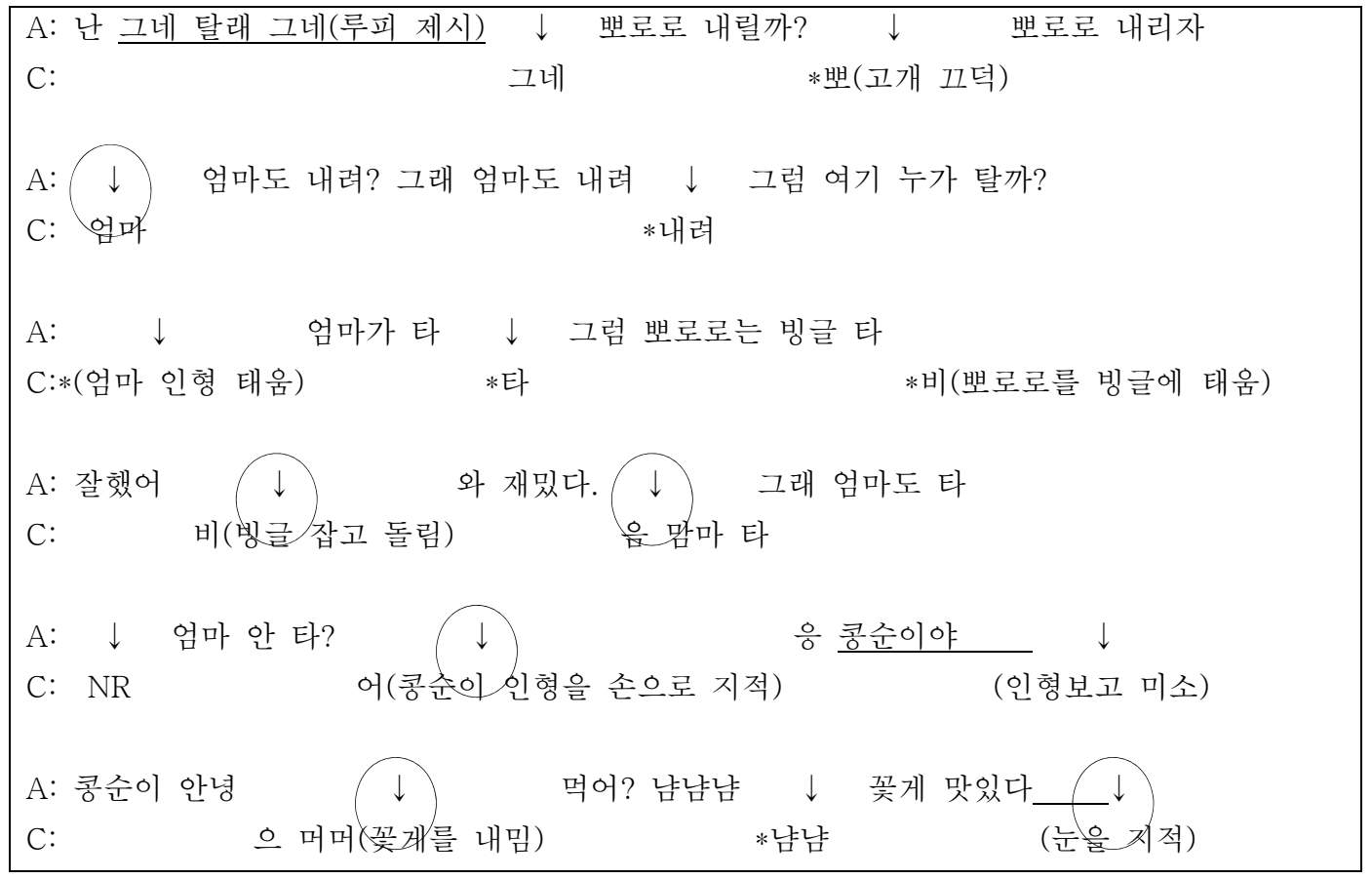

$\mathrm{A}=$ adult; C=child; $\downarrow=$ 아동의 차례; ( )=몸짓; $\mathrm{O}=$ 개시성; *= 비시각적 차례; 실선=연구자를 보거나 눈맞춤이 나타났을 때. 총 차례맡기 빈도15회, 발성 차례맡기 빈도 11 회; 몸짓 차례맡기 빈도 3 회, 무반응 빈도 1 회, 발성 개시성 빈도 5 회, 몸짓 개시성 빈도 1 회, 비시각적 발성 차례 빈도 5 회, 비시각적 몸짓 차례 빈도 1 회. 


\title{
국문초록
}

\section{Tait 비디오 분석법을 사용한 와우이식 영유아의 상호작용 평가}

\author{
정윤희 ${ }^{1} \cdot$ 윤미선
}

${ }^{1}$ 나사렛대학교 재활복지대학원 언어치료학과, ${ }^{2}$ 나사렛대학교 언어치료학과

배경 및 목적: 본 연구는 Tait 비디오 분석법을 사용하여 와우이식을 받은 청각장애 영유아의 상호작용 행동을 평가하여 이들의 상호 작용 발달 패턴을 일반 아동과 비교하는 것을 목적으로 하였다. Tait 비디오 분석법은 청각장애 아동의 상호작용 평가에 사용되고 있는 방법이다. 방법: 연구대상은 와우이식 영유아 9명과 이들과 언어연령을 일치시킨 일반 영유아 9 명, 생활연령을 일치시킨 일반 영유아 9 명의 총 27명이었다. 대상 영유아와 연구자와의 상호작용을 녹화, 전사하여 상호작용 행동을 발성과 몸짓에 따른 차례맡기 빈도, 개시 성 빈도, 청각적 인식(비시각적 차례) 빈도로 측정한 후 집단 간, 집단 내 요인의 혼합분산분석을 실시하였다. 결과: 와우이식 영유아집 단과 언어연령일치 집단은 모든 평가변인에서 유의한 차이를 보이지 않았다. 그러나 와우이식 영유아집단은 생활연령일치 집단과 발성 차례맡기, 몸짓 차례맡기, 비시각적 발성 차례 빈도에서 유의한 차이가 있었고, 발성 개시성, 몸짓 개시성, 비시각적 몸짓 차례 빈도는 유 의한 차이가 없었다. 논의 및 결론: 조기진단과 조기중재를 받은 와우이식 영유아집단은 생활연령일치 집단과는 상호작용 행동에서 차이를 보이나 언어연령일치 집단과는 유사한 발달 패턴을 보이고 있었다.

핵심어: 와우이식 영유아, 상호작용 평가, 차례맡기, 개시성, 청각적 인식

본 연구는 제1저자의 석사학위 논문을 수정한 것임.

\section{참고문헌}

곽금주, 김민화, 한은주(2004). 영아-어머니의 상호작용 방식과 영아기 사회적 의사소통능력. 아동학회지, 25, 111-128. 김명순, 김의향, 이유진(2012). 영아의 차례 맡기와 어휘발달 관계에 대한 단기 종단연구. 대한가정학회지, 50, 75-84.

김영태, 김경희, 윤혜련, 김화수(2003). 영유아 언어발달 검사(SELSI). 서울: 도서출판 특수교유.

성영주, 윤미선, 홍경훈(2010). 와우이식유아의 의사소통의도 분석. 언어청각장애연구, 15, 205-219.

신희선, 한경자, 오가실, 오진주, 하미나(2002). 한국형 Denver II 검사. 서울: 현문사.

연석정(2001). 청각장애유아의 의사소통의도 표현 특성 연구. 이화여자대학교 대학원 석사학위 논문.

윤미선(2010). 청각장애 영유아의 조기중재를 위한 의사소통 평가도구 구성의 타당성. 언어치료연구, 19, 211-232.

윤미선, 최은아(2010). 청각장애 영유아 조기중재: 의사소통 능력의 평가. 언어청각장애연구, 15, 1-19.

홍경훈, 김영태(2005). 종단연구를 통한 ‘말늦은 아동(late-talker)’의 표현어휘발달 예측요인 분석. 언어청각장애연구, 10, 1-24.

Robert E. Owens (2005). 언어발달(제6판, 이승복, 이희란 공역). 서울: 시그마프레스. 